九州大学学術情報リポジトリ

Kyushu University Institutional Repository

Changes in the Chemical and Physical Soil Conditions of a Marginal Land Planted with Three Strata Forage System under Three Years of Grazing

Hasan, Syamsuddin

Animal Nutrion Department, Animal Husbandry Faculty, Hasanuddin University

Masuda, Yasuhira

Shimojo, Masataka

Natasir, Asmuddin

Animal Nutrion Department, Animal Husbandry Faculty, Hasanuddin University

https://doi.org/10.5109/4630

出版情報: 九州大学大学院農学研究院紀要. 50 (1)，pp.129-133，2005-02-01. Faculty of Agriculture, Kyushu University

バージョン：

権利関係 : 


\title{
Changes in the Chemical and Physical Soil Conditions of a Marginal Land Planted with Three Strata Forage System under Three Years of Grazing
}

\author{
Syamsuddin HASAN ${ }^{1 *}$, Yasuhisa MASUDA, Masataka SHIMOJO \\ and Asmuddin NATSIR ${ }^{1}$
}

\author{
Laboratory of Animal Feed Science, Division of Animal Science, Department of \\ Animal and Marine Bioresource Sciences, Faculty of Agriculture, \\ Kyushu University, Fukuoka 812-8581, Japan \\ (Received October 30, 2004 and accepted November 11, 2004)
}

\begin{abstract}
This study was conducted to evaluate the changes in the chemical and physical soil conditions of marginal land planted with three strata forage system (TSFS) during three years of grazing period. A-3.2 ha of marginal land was divided into eight plots (each plot was $40 \mathrm{~m} \times$ $100 \mathrm{~m}$ ), then four plots were planted with TSFS and other four plots were planted with native grasses (Control: C). Eight head of male Bali cattle (average body weight $150 \mathrm{~kg}$ ) grazed continuously in the experimental land ( 1 cattle/plot). The experiment was carried out for three corısecutive years (1992-1995).

Results of this study indicated that at the end of the third year, the physical and chemical conditions of the soil planted with TSFS were better than the C. Sand percentage in the soil of the TSFS was less than that of the $\mathrm{C}$ (71.81 versus $77.86 \%)$. Total-N, total-P and total-K contents of the TSFS were higher than those of the $C(0.27$ versus $0.20 \%, 224.07$ versus $114.34 \mathrm{ppm}, 6.89$ versus $5.79 \mathrm{ppm})$. Similarly, top soil of the TSFS was thicker than that of the C (17.86 versus $9.53 \mathrm{~cm})$, and water run off of the TSFS was slower than that of the $\mathrm{C}(19.88$ versus $34.88 \mathrm{~mm} / \mathrm{h}$ ). However, soil $\mathrm{pH}, \mathrm{P}$ Bray and infiltration rate were not significantly different $(P>0.05)$ between the TSFS and the $C(6.81$ versus $6.78 ; 16.43$ versus $17.01 \mathrm{ppm}$, and 1.55 versus $1.40 \mathrm{~mm} / \mathrm{h}$, respectively). Results also revealed that the experimental period affected soil $\mathrm{pH}$, total- $\mathrm{N}$, infiltration rate, top soil, and water run off in the TSFS and the $\mathrm{C}$, but the effects among the periods were not persistent. Analysis also showed that there was no interaction between the planting system (TSFS and C) and the growing periods.
\end{abstract}

\section{INTRODUCTION}

The number and the area of marginal/critical land in Indonesia are continuously increasing with the advance of time (Anonymous, 1987). Leaving this condition without solving it might worsen the environmental conditions. The occurrence of marginal/critical land is caused by lack of water due to the long period of dry season, usually 7-8 months through a year. Another factor increasing the marginal/critical land is a farming system recognized as "Shifting Cultivation". In this system, shifting cultivation farmers always look for fertile soil and leave it when fertilization of the soil decreases, usually after several years utilization. Normally, the land left by the farmers then will be dominated by Imperata cylindrica. As the optimized utilization of the marginal/critical land, one

\footnotetext{
1 Animal Nutrition Department, Animal Husbandry Faculty, Hasanuddin University, Ujung Pandang, Indonesia (90245)

* Corresponding author (E-mail: hasan_syam@hotmail.com)
} 
alternative is to plant animal feed plants. The advantages of planting animal feed plants in the critical land are the reduction in soil erosion and the increase in soil fertility and soil organic matter, and the improvement of physical structure of the soil (Nitis et al., 1989). Also it helps soil recovery, and prevents soil destruction and infertility of the soil (Soerodjotanojo, 1983; Seta, 1987).

The purpose of this study was to evaluate the changes in physical and chemical soil conditions of marginal/critical land planted with three strata forage system under three years grazing.

\section{MATERIALS AND METHODS}

This research was conducted on a 3.2 ha marginal land. The land was divided into four blocks, then each block was divided into two units, each unit was $40 \mathrm{~m} \times 100 \mathrm{~m}$. Then, one unit in each block was planted with animal feed plants with three strata forage system (TSFS) and the other was planted with native grasses (Control: C), therefore, the total experimental units were 8, four units for the TSFS and four units for the C, respectively. The TSFS was arranged as follows. The outset of the unit was planted with fodder trees, Leucaena leucocephala and Gliricidia maculata, with $0.5 \mathrm{~m}$ spacing between those two plants for stratum 3. The inner zone of the unit, five meters from the fodder trees, was planted with buffelgrass (Cenchrus ciliaris) and siratro (Macroptilium atropurpureum) for stratum 2 , and the center of the unit was planted with setaria (Setaria sphacelata) and centro (Centrosema pubescens) for stratum 1 (Fig. 1).

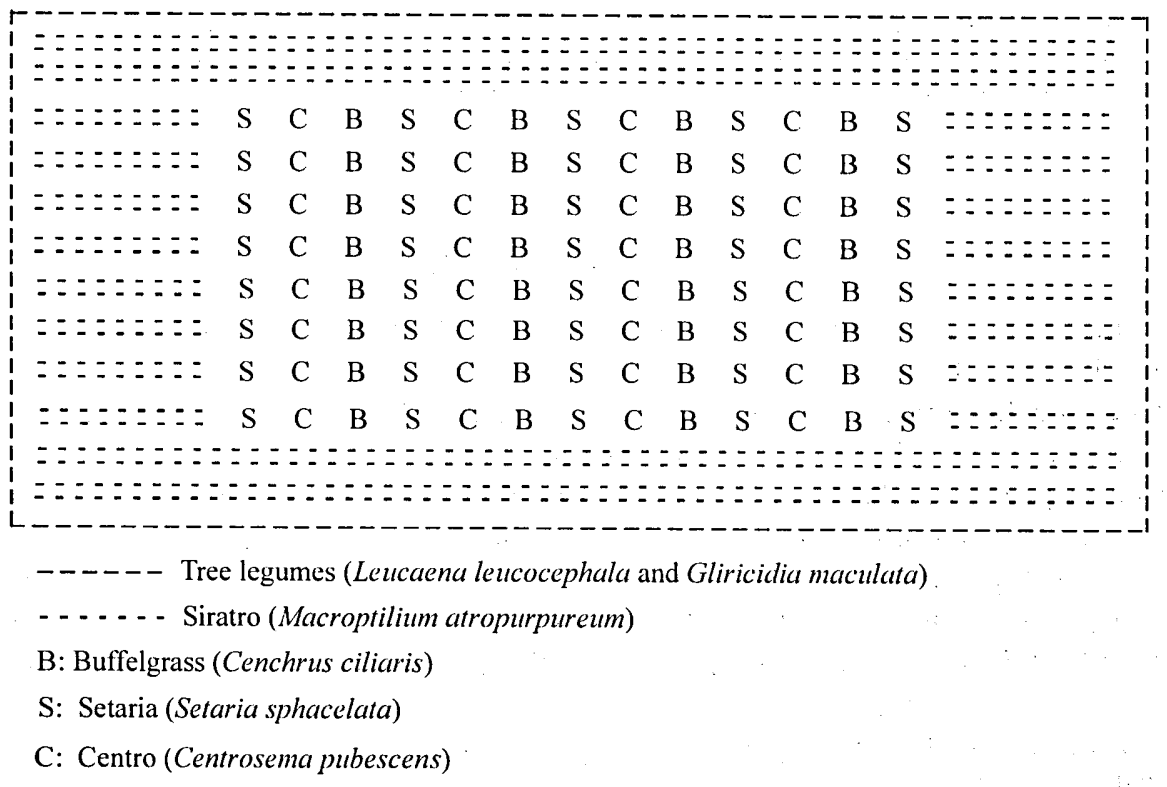

Fig. 1. A scheme of three strata forage system in each unit of the experimental marginal land. 
This research was conducted for three years, and each year was divided into two periods, namely the period of dry season and that of wet season. The total of experimental periods were six (P1, P2, P3, P4, P5 and P6). One year following planting of the TSFS, 8 head of male Bali cattle, average body weight $150 \mathrm{~kg}$, grazed on the experimental land ( 1 cattle/unit). Water was always available at the experimental land, while minerals for cattle were supplemented when needed.

The experiment was carried out according to the split plot design. The main plots were the TSFS and the C, and the sub plots were growing periods (P1, P2, P3, P4, P5 and P6). The physical and chemical conditions of the experimental land were analyzed according to Black (1965). General linier models of SAS (1985) were used to analyze the experimental data.

\section{RESULTS AND DISCUSSION}

Until the end of the sixth period, general condition of the experimental land became better. Table 1 shows physical structure of the experimental land. There was a reduction in the sand percentage in the soil of TSFS land (71.81\%) compared with the control land soil $(77.86 \%)$. This result agrees with a study (Nitis et al., 1989) indicating that physical structure of the land planted with TSFS was better than that of the land without TSFS.

Table 2 shows the chemical conditions of the experimental land. Statistical analysis showed that total-N, total-P and total-K contents of the land with TSFS were higher $(P<0.01)$ than those of the control land $(0.27$ versus $0.20 \%, 224.07$ versus $114.34 \mathrm{ppm}$, 6.89 versus $5.79 \mathrm{ppm})$. However, soil $\mathrm{pH}$ and $\mathrm{P}$ Bray content were not affected by the planting system $(P>0.05)$. One of the reasons for improving the soil nutrients was the capability of legume in supplying nitrogen to the soil. These results agree with the report by Nitis et al. (1989) who showed that percentages of salts and organic matter of the soil with TSFS increased compared with those of the land without TSFS. The report by Reksohadiprodjo (1985) revealed that the land planted with animal feed plants had better conditions due to its capability of conserving soil nutrients from erosion.

Table 1. Physical structure of soil in the land of three strata forage system (TSFS) and in the land of native grasses (C).

\begin{tabular}{ccccccccc}
\hline Parameters & Treatments & \multicolumn{7}{c}{ Periods } \\
& & P1 & P2 & P3 & P4 & P5 & P6 & Mean \\
\hline Dust & TSFS & 22.18 & 24.50 & 31.65 & 15.60 & 14.60 & 16.27 & $20.80 \mathrm{a}$ \\
(\%) & C & 15.56 & 16.92 & 17.68 & 14.81 & 10.50 & 10.26 & $14.29 \mathrm{~b}$ \\
\hline Clay & TSFS & 9.14 & 5.88 & 3.87 & 7.39 & 7.40 & 5.02 & $6.45 \mathrm{a}$ \\
(\%) & C & 10.06 & 3.96 & 6.10 & 7.82 & 10.96 & 9.55 & $8.08 \mathrm{~b}$ \\
\hline Sand & TSFS & 68.81 & 69.75 & 64.41 & 78.16 & 71.00 & 78.70 & $71.81 \mathrm{a}$ \\
(\%) & C & 74.38 & 79.44 & 76.21 & 75.81 & 81.13 & 80.16 & $77.86 \mathrm{~b}$ \\
\hline
\end{tabular}

$\mathrm{a}, \mathrm{b}$ : Means with different superscripts in the same column for each parameter were significantly different $(P<0.01)$. 
Table 3 shows the physical condition of the experimental land. Statistical analysis indicated that the top soil of the marginal land with TSFS was thicker $(P<0.01)$ than that of the control land (17.86 versus $9.53 \mathrm{~cm}$ ). Moreover, water run off of the marginal land with TSFS showed a significant decrease $(P<0.01)$ than that of the control land $(19.88$ versus $34.88 \mathrm{~mm} / \mathrm{h}$ ). However, the infiltration rate did not differ between the TSFS and the $\mathrm{C}$. The improvement in physical conditions, especially in the treated land was closely related to the condition of vegetation on the TSFS which showed better growing compared with the control land. Again, this study agrees with the report by Nitis et al. (1989) who stated that the erosion rate of land with TSFS was $57 \%$ less than that of non-TSFS land and the decrease was caused by high density roots of the TSFS land.

Table 2. Chemical characteristics of soil in the land of three strata forage system (TSFS) and in the land of native grasses (C).

\begin{tabular}{ccccccccc}
\hline Parameters & Treatments & & \multicolumn{7}{c}{ Periods } & & \\
& & P1 & P2 & P3 & P4 & P5 & P6 & Mean \\
\hline pH & TSFS & 6.93 & 6.65 & 6.51 & 6.83 & 6.86 & 7.05 & $6.81 \mathrm{a}$ \\
& $\mathrm{C}$ & 6.80 & 6.85 & 6.54 & 6.78 & 6.80 & 6.93 & $6.78 \mathrm{a}$ \\
\hline Total-N & TSFS & 0.30 & 0.39 & 0.21 & 0.21 & 0.25 & 0.23 & $0.27 \mathrm{a}$ \\
(\%) & $\mathrm{C}$ & 0.14 & 0.21 & 0.26 & 0.27 & 0.17 & 0.16 & $0.20 \mathrm{~b}$ \\
\hline P Bray & TSFS & 19.07 & 16.09 & 15.81 & 15.30 & 14.51 & 17.80 & $16.43 \mathrm{a}$ \\
(ppm) & $\mathrm{C}$ & 20.33 & 17.65 & 15.21 & 14.57 & 18.35 & 15.94 & $17.01 \mathrm{a}$ \\
\hline Total-P & TSFS & 203.60 & 187.50 & 257.60 & 205.60 & 258.22 & 228.87 & $223.57 \mathrm{a}$ \\
(ppm) & $\mathrm{C}$ & 106.60 & 87.75 & 135.75 & 129.98 & 115.98 & 115.63 & $115.28 \mathrm{~b}$ \\
\hline Total-K & TSFS & 8.10 & 4.51 & 4.54 & 10.31 & 5.32 & 8.67 & $6.91 \mathrm{a}$ \\
(ppm) & $\mathrm{C}$ & 3.82 & 3.03 & 2.93 & 13.34 & 3.84 & 7.80 & $5.79 \mathrm{~b}$ \\
\hline
\end{tabular}

a, b: Means with different superscripts in the same column for each parameter were significantly different $(P<0.01)$.

Table 3. Physical condition of the land of three strata forage system (TSFS) and in the land of native grasses (C).

\begin{tabular}{ccccccccc}
\hline Parameters & Treatments & \multicolumn{7}{c}{ Periods } \\
& & P1 & P2 & P3 & P4 & P5 & P6 & Mean \\
\hline Infiltration & TSFS & 3.25 & 1.75 & 1.32 & 0.75 & 1.08 & 1.16 & $1.55 \mathrm{a}$ \\
rate (mm/h) & $\mathrm{C}$ & 1.75 & 1.25 & 0.87 & 1.25 & 1.19 & 2.09 & $1.40 \mathrm{a}$ \\
\hline Top Soil & TSFS & 9.88 & 12.75 & 10.75 & 24.75 & 24.25 & 24.75 & $17.86 \mathrm{a}$ \\
(cm) & $\mathrm{C}$ & 7.20 & 7.75 & 6.75 & 9.25 & 9.25 & 14.00 & $9.03 \mathrm{~b}$ \\
\hline Water Run & TSFS & - & - & 19.25 & 22.25 & 18.00 & 20.00 & $19.88 \mathrm{a}$ \\
Off (mm/h) & C & - & - & 33.75 & 33.75 & 33.50 & 36.00 & $34.25 \mathrm{~b}$ \\
\hline
\end{tabular}

$\mathrm{a}, \mathrm{b}$ : Means with different superscripts in the same column for each parameter were significantly different $(P<0.01)$. 
Experimental periods significantly affected the soil $\mathrm{pH}$, total- $\mathrm{N}$, infiltration rate, top soil, and water run off of the soil, however, the effects were not persistent among the periods. Analysis also showed that experimental periods did not affect the total-P and $\mathrm{P}$ Bray of the soil.

\section{CONCLUSIONS}

The improvement in the characteristic of the soil of the land planted under the TSFS was still obvious even after three years consecutive grazing.

\section{ACKNOWLEDGEMENTS}

The author would like to thank the DP4M Depdikbud for funding the research through Hibah Bersaing Project I.

\section{REFERENCES}

Anonymous 1987 To overcome the problem of shifting cultivating farmer. Forest No. 23. Jakarta

Black, A. S. 1965 Soil Analysis Method. American Society of Agronomy, Madison, USA

Nitis, I., K. Lana, M. Suarna, W. Sukanten, S. Putra and W. Arga 1989 Three strata forage system for cattle feeds and feeding in dry land farming area in Bali. Fac. Animal Husbandry, Udayana University, Bali

Reksohadiprodjo, S. 1985 Production of Tropical Forage. BPFE, Yogyakarta

SAS 1985 SAS User's Guide: Statistic. SAS Ins., Inc. Cary, NC

Seta, A. K. 1987 Conservation of Soil and Water Resources. Kalam Mulya, Jakarta

Soerodjotanojo, S. 1983 Guidance for Lamtoro gung palntation. PN Balai Pustaka, Jakarta 